\title{
Trends in the history of research on the problem of violence in the Old Testament
}

\author{
S D Snyman \\ Department of Old Testament \\ University of the Orange Free State
}

\begin{abstract}
Trends in the history of research on the problem of violence in the Old Testament
\end{abstract}

Violence as theological problem is a relative newcomer to the scene of Old Testament studies. It was only during the 1970's that violence was given major attention by Old Testament scholars. In a number of studies the main focus was on Yahweh and his relation to violence. By the late 1970's the theories of Rene Girard on violence were applied to the Old Testament and played an important role in the thinking of Old Testament scholars on violence. In the last part of the article proposed solutions to the problem of violence in the Old Testament are discussed.

\section{INTRODUCTION}

Violence as theological problem is a relative newcomer to the scene of Old Testament studies. Despite the many instances of violence recorded in the Old Testament, Schwager ${ }^{1}$ in his study found that there are more or less a thousand cases in which Yahweh's own violence comes to the fore, while in another hundred cases Yahweh commands that other people be put to death and that there are more than sixhunderd other cases where a nation, king or individual annihilate someone - relatively little attention has been paid to the problem by Old Testament scholars. Scholars ${ }^{2}$ have pointed out that there is not an extensive and adequate discussion of the problem in the major books on Old Testament theology (Eichrodt 1933, 1939, Von Rad 1957, 1960, Zimmerli 1972, Westermann 1978, Clements 1978, Vriezen 1955, Childs 1986 and recently Preuss 1991). The same conclusion is reached when books on the ethics of the Old Testament (Van Oyen, Kaiser, Wright) or books on the anthropology of the Old Testament (Wolff) are consulted.

It was only during the late 1970's that Old Testament scholars began to direct their attention to this problem. In this contribution the aim is not to provide a thorough history of research on the subject of violence in the 
Old Testament. Only the major trends in the history of the research on the problem of violence in the Old Testament will be highlighted ${ }^{3}$.

\section{THE PROBLEM OF VIOLENCE IN THE OLD TESTAMENT}

Scholars have no difficulty in bringing the problem of violence in the Old Testament to the attention of their readers. From a variety of angles scholars relate the many and varied instances of violence recorded in the Old Testament. Paging through the Old Testament reveals the one violent incident after the other. According to Schwager ${ }^{4}$ violence is the most central theme in the Old Testament ${ }^{5}$, while Lohfink ${ }^{6}$ noted that the Old Testament is replete with the theme of violence. Schenker ${ }^{7}$ notes that the Old Testament would not count as a master example for the ideal of nonviolence.

Ebach $^{8}$ notes how the main salvation traditions of Israel time and again contain scenes of violence. History of mankind begins with the gruesome story of Abel being murdered by his brother Cain (Gen 4:1-16). Yahweh's redemption of his people from Egypt begins with Moses bearing the title "servant of Yahweh" - murdering an Egyptian. Israel took possession of the land promised to them by Yahweh by way of war and violence as recorded in the book of Joshua (Jos 5-11). The prophets (Amos 1-2; 3:10; 6:1-7; Hos 4:1-2, 12:2; Mic 6:12, 7:2; Is 59:2-8; Ezek 22:1-27) had to speak out against violence on more than one occasion, while they themselves were also victims of violence.

Villar ${ }^{9}$ notes in similar vein how the conquest of Canaan took place in violent ways. Deuteronomic tradition reviews Israel's history from Moses to the fall of Jerusalem where the dominant theme is violence. The deuteronomistic history, giving a theological explanation for the disaster of the exile, recalls how king "Manasseh killed so many innocent people that the streets of Jerusalem were flowing with blood..." (II Ki 21:17). The Priestly writer sees the Flood as God's punishment for all the violence that had gone before. According to Lohfink ${ }^{10}$ the sin of the whole world is summed up in the one word hamas in Genesis 6:11,13 which is at the same time the cause for the Flood.

In the book of Psalms ${ }^{11}$ the problem of violence also comes to the surface in the so-called psalms of wrath, while the problem of violence is also touched upon in the wisdom literature of the Old Testament. 
A number of scholars take as their point of departure the occurrence of violence in current society and try to establish a relation between violence prevailing in society with the violence related in the Old Testament. How can or should the violence in society be aligned or connected with the violence related in the Old Testament?

Two rather opposing answers are given on this question. On the one hand scholars make mention of the fact that in many cases in the history of the Christian church the Old Testament was appealed to for the legitimation of violence in society. Mention is made of the Inquisition, the Crusades and the persecution of heretics as examples of an uncritical use of the Old Testament to legitimise violence in society ${ }^{12}$. World War I (19141918) and II (1939-1945) as well as civil wars and wars of religion were often fought with an appeal from the Old Testament tales of war and violence $^{13}$. Vervenne ${ }^{14}$ noted that German Old Testament scholars published books on the Old Testament and war during World War I, bearing titles such as "Das Alte Testament und unser Krieg" (Kittel) and "Israelitisch Heldentum und Kriegfrömmigkeit im Alten Testament" (Gunkel).

On the other hand there are scholars who find the many and disturbing instances of violence recorded in the Old Testament an embarrassment for both themselves and Christian lay people. Texts speaking of violence are not only an embarrassment, they are also morally repulsive and theologically problematic, because violence is committed either in the name of Yahweh or at his hand, says Brueggemann ${ }^{15}$. While violence can be depicted as a central problem for mankind in general, one does not find a ready made solution for the problem in the Old Testament. On the contrary, the Old Testament is a collection of writings full of violence, in fact, the Old Testament has been called one of the bloodiest books in world literature ${ }^{16}$. While the whole world - marred by war, bloodshed of innocent victims of random violence, aggression, murder, child abuse and a host of other violent actions - is looking for peace, the Old Testament calls for violence. The Old Testament would not count as a master example for a society wishing to be free from violence ${ }^{17}$.

The result of this kind of reasoning is that the voice of the Old Testament on the problem of violence is not heard. The violence occurring in the Old Testament tends to be either repressed or relativized or even eliminated. Violence in society is a reality which should be dealt with inter alia in a theological way ${ }^{18}$.

Confronted with the problem of violence in current societies and the possible relatedness to the Old Testament, scholars reacted in one of two 
possible ways. Some argue that the Old Testament supports violence and can be used as a legitimation of violence in a society. Other scholars find the occurrence of violence to be an embarrassment for them with the result that not much attention has been paid to the problem leading to the effect that the voice of the Old Testament was virtually silenced on this particular issue $^{19}$. Lohfink ${ }^{20}$ puts it rather aptly: "Die Bibelwissenschaftler unter uns haben es gelernt, in mehreren Welten gleichzeitig zu leben... Wir lesen die Literatur. Wir gehören zu ihren Autoren. Wir diskutieren darüber in unseren Vorlesungen. Aber wenn wir dann sonntags predigen, sprechen wir nur über den Gott des Friedens und der Versöhnung".

\section{YAHWEH AND VIOLENCE AS PROBLEM IN THE OLD TESTAMENT}

That Yahweh was closely related to violence in the Old Testament is obvious even from a cursory reading from the Old Testament. In a number of studies the focus of attention was on Yahweh and his relation to violence.

In $1978 \mathrm{H} \mathrm{D}$ Preuss made a contribution in a book on power and violence $^{21}$ where he deals with the issue of power and violence from the perspective of the Old Testament. Preuss begins his contribution by making a few remarks on hermeneutical questions and the relationship between the Old and New Testaments. In the second part he points out how the Old Testament was often misused in the past to legitimise violence and warns against an uncritical application of Old Testament texts to present political actions. In the third and major part of his paper he deals more directly with the Old Testament. He concentrates on the way in which Yahweh is presented in the Old Testament and points out that Yahweh is often presented as a warrior (Ex 15:3). Israel was redeemed from the Egyptian powers by way of a military victory of Yahweh. In the prophetic literature there is a constant hope of a victory of Yahweh and Israel on their common enemies - the other nations - culminating in a final 'Day of Yahweh', even though Yahweh is also known as a merciful God. He doubts whether an all encompassing peace among all nations is really foreseen in the Old Testament despite texts as Isaiah 2:1-4. Israel's relationship with the other nations is mainly determined by matters of war rather than lasting peace. When Yahweh reveals himself in theophany and epiphany, he does so in power and with might ${ }^{22}$. Preuss concludes his contribution with a final paragraph on Yahweh's eschatological violence. By this, Preuss means that the end of times, in an eschatological way or 
even from an apocalyptic perspective beyond the borders of time, Yahweh's final intervention will come about in a violent way. The nations and godless people opposing God and his people will be destroyed. In sum, Yahweh is a war-like God.

Also in 1978 Schwager ${ }^{23}$, a systematic theologian, published a book where he deals inter alia with the problem of violence in the Old Testament. Schwager leaves little doubt that the Old Testament portrays an violent God. Just as human violence is a universal phenomenon, so is divine violence also a universal phenomenon. Divine violence in the Old Testament can be grouped into four categories according to Schwager ${ }^{24}$ : There are a few instances in the Old Testament where divine violence seems to be an irrational act on the side of Yahweh. Secondly, divine violence occurs where there is an outpour of God's wrath 25 because of the evil deeds of people. Divine violence can also occur in an indirect way where people are commissioned by God to execute his wrath on his behalf on other people. Lastly, man brings divine violence upon himself by his own deeds.

In 1980 Ebach published a book - the first one to be published by an Old Testament scholar on the theme of violence - concentrating in one of the chapters on the phenomenon of violence in the Old Testament. The aim of the book was to establish whether or not biblical pronouncements can shed light on how responsible behaviour should look like in times of war, violence and terrorism.

Ebach remarks that Yahweh is portrayed as saviour of his people from the bondage of Egypt, but in the act of redeeming his people there is violence ${ }^{26}$. Redemption and violence are therefore inextricably tied to each other. Yahweh is saviour and a performer of violence at once. However, Israel honour Yahweh not for the violence in the act of delivering them from Egypt, but for the redemption they experienced. There are also indications in the Old Testament that Yahweh does not condone violence in Israel. Amos 2:14-16 serves as an example of Yahweh's attitude against violence in the society of Israel. War and violence do not have the last word in God's history with mankind 27.

Lohfink in a number of publications ${ }^{28}$ was (and is) a powerful contributer to the theme of violence in the Old Testament. Here one does not only find human acts of violence, God himself is a violent God ${ }^{29}$. The reason why this is the case, argues Lohfink following anthropological suppositions, is because there is an analogy between society and the god(s) of a given society. Violent societies have violent gods ${ }^{30}$. A violent image of God is only a reflection of a violent society. This in turn gives reason to 
the fact why the cult of God is also violent, because of the animals which must be put to death in order to be sacrificed ${ }^{31}$.

Vervenne ${ }^{32}$ also devoted his attention to the problem of violence in the Old Testament. He is in agreement with Lohfink that the Old Testament gives evidence of both a violent society and a violent God. Remarkably, however, is that the Old Testament does not hesitate to speak quite openly of the violence perpetrated by the people of Israel. No secret is made of the irreversible reality of violence. The second observation Vervenne ${ }^{33}$ makes, is that one should keep in mind that the Old Testament is primarily made up of pieces of proclamation. Texts give witness to matters in order to convince. The conclusion he came to is that the violence one encounters in the writings of the Old Testament seems to function as verbal violence. The language of violence is in many respects the language of the powerless (Israel) which looks to God (Yahweh) for strength.

A theme closely connected to the theme of Yahweh's relatedness with violence is the question of Yahweh and (holy) war ${ }^{34}$. It was a book published by Von $\mathrm{Rad}^{35}$ in 1951 who really made this term a well-known one in Old Testament scholarship. According to Von Rad, the concept of a "holy war" was first and foremost coming from a cultic Sitz. Soldiers prepared themselves for war through fixed rituals such as cleaning and sexual ascetism; the soldiers and their weapons were consecrated; sacrifices were offered and Yahweh's guidance was called upon to give the enemy into their hands in victory. It was then believed that Yahweh would fight the war for his people. It follows naturally that victory was owing to Yahweh's power and not to military strategies. Israel was even commanded to reduce its forces and since Yahweh headed Israel's forces, booty belonged to him alone. Once the battle was over, the soldiers return to civilian life ${ }^{36}$.

Ebach draws attention to the fact that the term "holy war" does not occur in the Old Testament and that it was not strange that military matters were also seen from a religious or cultic perspective. In fact, every dimension of life in ancient Israel was seen from a religious perspective. It can therefore not be conferred that war was elevated to a special position over and above other spheres of life. The wars fought in ancient Israel were Yahweh's wars. Victory in wars thus meant that it was Yahweh's victory over his enemies, despite the military power of his own people. There was thus no glorification of war or violence in Israel ${ }^{37}$. It would therefore be better to refrain from the term "holy war" and rather opt for the term "Yahweh war" as this would be a much more appropriate term to be used in this regard ${ }^{38}$. 
Vervenne ${ }^{39}$ echoes the appeal made by Ebach. He argues that a distinction must be made between "religious" and "holy" in the sense that the term "holy war" aims at making something that in se is bad (the disvalue of war) into something good (the value of the "holy"). Although the texts of the Old Testament are permeated with violence, violence and war are never glorified.

\section{THE INFLUENCE OF THE THEORY OF R GIRARD ON VIOLENCE}

The first publications of Old Testament scholars which touched upon the problem of violence in the Old Testament, (Preuss in 1978 and Ebach in 1980), show no influence of the theories of Rene Girard on the phenomenon of violence which played so an influential role in the debate on violence in the Old Testament during the 1980's. In 1978 Raymund Schwager, a systematic theologian, published a book on violence in Scripture in which he applied the theories of Girard on the Old and New Testament respectively ${ }^{40}$. The theories of Girard came to the attention of Lohfink, an eminent Old Testament scholar, via the publication of Schwager ${ }^{41}$. Via Lohfink Girard dominates the scene of Old Testament reflection on violence. Vervenne ${ }^{42}$ notes how this development marks a shift in the investigation of violence: scholars no longer limit themselves to compiling statistical lists of violent texts or their literary-historical elucidation; they also try to let the insights they gained in this way function within the context of an anthropological and theological questioning, above all the ideas about the origins of violence, society and religion advanced by Girard.

Because of the influence Girard exercised on the study of violence as problem in the Old Testament it is necessary to pay some attention to the theory of Girard on violence. Girard's theory on violence was published originally in a French publication ${ }^{43}$ and was later translated into English ${ }^{44}$.

The title of Girard's book, Violence and the Sacred, suggests a relation between violence and the sacred. It is exactly this supposed relationship which Girard explores in the first chapter of his book. If violence cannot be satisfied by the real victim it will seek and will always find a surrogate victim, a "sacrificable" victim. The function of sacrifice is to quell violence within the community and to prevent conflicts from erupting. In primitive societies the risk of unleashed violence is so great and the cure so problematic that the emphasis naturally falls on prevention. The preventitive measures naturally falls within the domain of religion where they can assume a violent character. Violence and the sacred are thus 
inseparable. Violence in society is limited by another kind of violence, the violence of the sacrificial act ${ }^{45}$.

It is in this respect that mention should also be made of the scapegoat-mechanism Girard proposes. Violence can take enormous proportions in a given society. Girards contends that the mechanism of reciprocal violence can be described as a vicious circle - a circle which can be defined in terms of vengeance and reprisals. The mimetic character of violence can be so intense that once violence is installed in a community, it cannot burn itself out ${ }^{46}$. When violence erupts in society and becomes a threat to society as a whole, there comes a moment when aggression centres all of a sudden on one individual who is chosen at random. Then the violence of all centres on him, bearing the violence of all the parties involved in the conflict. At the supreme moment of the crisis, the very instant when reciprocal violence is abruptly transformed into unanimous violence and the two faces of violence seem to be juxtaposed, the extremes meet. The surrogate victim serves as catalyst in this metamorphosis ${ }^{47}$. So violence comes, at least temporarily, to an end when the scapegoat bears the violence of all by being sacrificed. The reciprocal cycle of violence has been broken when all the violence of the community is channeled into a single collective act of murder in which the designated victim is killed. Opposing parties unite against the scapegoat and the violence of the scapegoat be sacrificed, makes an end to the violence between parties in strife ${ }^{48}$. In this way, maleficent violence is replaced by beneficent violence. Violence is driven out by violence and the random victim is now hailed as the one who delivers the community from its own self-destructive tendencies ${ }^{49}$.

How and why does violence occur in society? According to Girardso violence is always mingled with desire. Desire itself is essentially mimetic, directed towards an object desired by the model. In all varieties of desires there are not only a subject and a object, but also a rival who desires the very same object as the subject. A triangular mimesis emerges destined to end in strife. Two desires converging on the same object lead inevitably to conflict and conflict turns to violence ${ }^{51}$.

The bridge from Girard to the Old Testament seems to be an easy one. Girard himself makes numerous references to the Old Testament in his work, inter alia the Cain and Abel story in Genesis, Abraham's sacrifice of Isaac in Genesis 22, Salomon's wise decision in I Kings 3:1623 and also to the book of Job and part of the Psalms. Girard's scapegoatmechanism lends it easily to texts such as Leviticus 16 as the Old Testament version of the scapegoat. 
As was noted above it was especially Lohfink who applied the theory of Girard to the problem of violence in the Old Testament. He is adamant that the theory of Girard should serve as starting point for an Old Testament reflection on violence: "Trotz der masslosen Einzelarbeit, die immer wieder mehr oder weniger zum Thema "Gewalt" hingeführt hat, und trotz der wenn auch nicht zahlreichen, so doch immerhin vorhandenen Ansätze von Zuwendung zur Sachfrage selbst besitzen wir eigentlich nichts, das die Frage im Blick die von uns auszulegenden Texte mit solcher Grundsätzlichkeit und Weite, aber auch mit solcher Deutekraft angeht wie der Girardsche Entwurf. Das ist die Lage. Von ihr müssen wir ausgehen" 52 . In many of his subsequent publications on the theme of violence in the Old Testament, Lohfink would refer to Girard. The theory of Girard serves as a theoretical framework within which the phenomenon of violence in the Old Testament is explained.

Lohfink was not the only one who followed Girard. North ${ }^{53}$, Ciholas $^{54}$ and others ${ }^{55}$ also reveal the influence of Girard and make the theory of his applicable to the Old Testament. Vervenne ${ }^{56}$ maintains that in treating the theme of violence and war in the Old Testament, the exegete must situate the question in a context broader than that of biblical scholarship. The problem is in the first place an anthropological one, which becomes especially acute whenever people apply it to their image of God as well. In reconstructing such an anthropological context, Vervenne finds the model of Girard a convenient one.

The theory set forth by Girard also met with some criticism. North 57 and also Rüterswörden ${ }^{58}$ pose serious questions to the thoughts of Girard and their application to the Old Testament.

A point of criticism that can also be raised against those who take the anthropological insights of Girard as their point of departure for treating the problem of violence in the Old Testament, is why they do so only in this regard? Why is only the problem of violence in the Old Testament approached from the angle of anthropology? Why is it that the same authors who advocate the anthropological approach to the problem of violence in the Old Testament, do not use the same approach for other problems in the Old Testament as well? Are there any other examples where an anthropological approach is applied to solve problems in the field of Old Testament studies? The strength of a theoretical framework lies in its ability to solve or at least explain problems in a satisfactory manner and it should also have applicability on a large area of problems in a particular field. 


\section{PROPOSED SOLUTIONS TO THE PROBLEM OF VIOLENCE IN THE OLD TESTAMENT}

Many and different answers were offered as proposed solutions to the problem of violence in the Old Testament. Preuss ${ }^{59}$ is not convinced that violence can be overcome in the Old Testament: "Trotz der Betonung des Friedensgedankens hat das Alte Testament zu einer prinzipiellen Kritik an Macht und Gewalt nicht gefunden, und auch der alttestamentliche Friedengedanke geht mit dem unseren keineswegs konform und steht $\mathrm{z}$ B einer ausschliesslichen Definition als 'Nicht-Krieg' sehr fern... Wo ferner das Ende aller Weltmächte und ihrer bösen Gewalt angekündigt wird, geschieht dies durch einen mit kriegerischer Macht und zerstörender Gewalt handelnden Gott, und dies nicht erst nach Texten alttestamentlicher Apokalyptik in Form von eschatologischer Gewalt Gottes". Although Preuss admits that there is (an eschatological) hope in the Old Testament for lasting peace, it is a debatable point whether this kind of eschatological peace would include all nations.

Ebach ${ }^{60}$ points out that the Old Testament does contain pronouncements of Yahweh who reacts against violence in the society of Israel, for example Amos 2:14-16. Violence, therefore, does not have the last word in God's history with people. Referring to texts such as Isaiah 2:2-5 and Micah 4:1-4, Ebach also holds (contra Preuss) that there is an eschatological hope for lasting peace and the eventual end of all violence and war in the Old Testament. The end of violence does not only happen in the realm of human relationships. The Old Testament's vision for a society free from violence also includes a society living in harmony with the wild animals. Conflict between man and animal will cease. For Ebach it is significant that it is not foreseen that animals are to be annihalated, but that a new way of co-existence between man and beast will be established (Is 11). Lastly, Ebach ${ }^{61}$ makes reference to Leviticus 19:18, recalling the translation of Martin Buber: Love your neighbour, because he is like you!

The solution Ebach proposes for the problem of violence in the Old Testament can be summarised as follows: (i) There are pronouncements in the Old Testament where Yahweh himself speaks out against violence in society; (ii) there is an eschatological hope for the end of violence resulting in a lasting peace encompassing all nations; (iii) the eschatological end of violence will also include the relation between man and animal and (iv) to love your neighbour is the foundation for a common humanity.

As was noted above Schwager is an important contributor to the discussion on violence as problem in the Old Testament. To Schwager 
there are four indicators in the Old Testament which point in the direction of violence being overcome. The first of these indicators Schwager ${ }^{62}$ calls the working of God through his word. He finds it quite significant that the ways of God to bring about justice, peace and love are done in a nonviolent way through his word. Although it may appear as if violence is much stronger than the word, it is fact not the case. The word of God is after all likened to a fire or a hammer (Jer 23:28ff). Schwager also quotes Hosea 1:7 "But to the people of Judah I will show love. I, the Lord their God, will save them, but I will not do it by war - with swords or bows and arrows or with horses and horsemen".

The second indicator Schwager ${ }^{63}$ finds is what he calls a new assemblage. When God liberates oppressed people from their enemies, he also gathers them anew. In this new community there is no violence and people will live in peace with one another, because they will adhere to the voice of God.

The third indicator Schwager ${ }^{64}$ calls the spirit of God and love among people. Schwager quotes various examples (Abraham and Lot, David and Jonathan, Joseph and his brothers, Solomon and the dispute between two women about the baby) in the Old Testament where disputes between people are settled in a non-violent, peaceful way. The spirit of God will bring the change of heart among people which is a prerequisite for love among them.

The fourth indicator Schwager ${ }^{65}$ finds in the figure of the Servant of Yahweh in Deutero-Isaiah. The Servant finds his strength in the Lord who teaches him. Remarkable is that the Servant does not react with violence against his enemies, to the contrary: "I bared my back to those who beat me. I did not stop them when they insulted me, when they pulled out the hears of my beard and spit in my face" (Is 50:6). The Servant (Is 53) is victim of those who perform violent actions against him. It also becomes clear that the Servant suffers vicariously for many others. The evil deeds of the violent ones are transferred to the Servant who carries their burden on their behalf. Schwager ${ }^{66}$ concludes: "Deuterojesaja macht klar, dass Gott nicht auf mirakulöse Weise die Neigung zur Gewalt aus der Menschenwelt entfernt. Wohl aber befähigt er seinen Knecht fremden Untaten zu tragen, ohne mit geleicher Münze heimzuzahlen".

For Lohfink it is important to note that the Old Testament does not elude the phenomenon of violence, but rather serves as representative of the whole of humanity. All nations at all times and all communities all over the world, sharing in a world of violence ${ }^{67}$. The Old Testament has the function of a mirror, unmasking the violence in the society of Israel and 
current societies, revealing violence for what it is. Lohfink ${ }^{68}$ is also convinced that a fundamental characteristic of the people of God is that of non-violence. So, although violence is still found in the community of Israel, there also appear the principles of a new society: right and justice, compassion and love. Is there a way out of violence? Can violence be overcome? According to Lohfink what Israel did not have, it longed for. The world of violence scatters and divides people, therefore the people of Yahweh longed for the time when God will gather all Israel together and when Jerusalem will be the center of a peace-filled world where swords will be beaten into ploughshares (Mic 4:2; Is 2:1-5) ${ }^{69}$.

The epoch when peace will finally dawn upon humanity is thus clearly an eschatological one, closely connected to the messianic expectation. How this new society will eventuate is seen in different ways. According to one point of view, the era where there will be no more violence will be preceded by a final act of violence. All evil powers will be destroyed in a massive final battle and then justice will reign ${ }^{70}$. Alongside this point of view, there is also another one. This is the way foreseen by Deutero-Isaiah in the figure of the Servant of Yahweh. Israel has to take on a new role, namely that of the Servant of Yahweh. The Servant accepts the violence he cannot avoid in the experience of the exile and God accepts him. Violence will be overcome by the Servant of Yahweh who will act as scapegoat ${ }^{71}$. According to Lohfink violence can be overcome. It will happen in a future eschatological act by the Servant of Yahweh.

Villar 72 notices three ways for Israel to cope with violence. Following Girard, Villar sees the sacrificial cult where an expiatory victim is sacrificed as a means of coping with violence. However, prophetic criticism leveled against the practice of sacrifice discredits it as a method of overcoming violence. Yahweh's Torah which result in justice, is a second feature in Israel whereby violence can be overcome. Violence done to the poor and defenceless was regarded as a sin against Yahweh, who took the poor under his protection. It was especially the prophets who anchored their message in a social ethic and in the morality based on the covenant. In the third instance Villar highlights the idea of the kingdom of the Messiah. In a final eschatological war Yahweh's kingdom will mean a political and social liberation from Israel's oppressors and Jerusalem will become a center of world peace, while God's people will be set free from violence.

In his attempt to provide an answer on the issue of violence in the Old Testament, Vervenne ${ }^{73}$ draws attention to the fact that in the Old Testament violence and war are always related to God in one or other 
specific way. From this observation Vervenne makes the conclusion that humans may not use violence to realize their individual or political aspirations or to bring an end to their enemies. Violence and war are indeed criticized in the Old Testament and non-violence is an essential characteristic of God's people.

Schenker did not engage directly in the theological debate on violence in the Old Testament, but in a monograph ${ }^{74}$ and in an article 75 on violence, he did make a contribution to the solution of the problem of violence in the Old Testament. According to Schenker the Old Testament never glorifies violence, but rather has various measures to curb violence in society. These measures he finds in the judicial system of Israel, in particular the laws governing justice between families in strife. There are also various measures taken to protect the powerless and defenseless in the Old Testament. Violence is also sometimes kept in check by counterviolence so that violence can serve as a control mechanism on violence. Conflict between parties resulting in violence can also be resolved by mutual compromise. Violence can also be resolved by an act of reconciliation which is proof of God's willingness to reconcile with human beings. In the Old Testament the Joseph-narrative (Gen 37-50) serves as an example of how conflict can be resolved by reconciliation ${ }^{76}$.

It is clear from this survey of trends in the history of research on violence in the Old Testament that scholars have difficulty in relating a kind, forgiving and loving God to a violent God. The violence so apparent in the Old Testament will therefore only be overcome in a final eschatological epoch. The solution to violence is thus an eschatological one. The figure of the Servant of Yahweh also plays a prominent part in the eventual overcoming of violence ${ }^{77}$. In the interim period where violence still prevails, one should keep in mind that Yahweh speaks out against violence in the Torah as well as through the prophets; that there are measures to be taken so that violence in society can at least be curbed and that the command to love one's neighbour was a way to conquer violence. A further observation that has to be made is that the scholarly debate on this issue up to now has tended to focus on the phenomenon of violence as such. Little attention has been paid to specific statements the Old Testament has to make on violence in for instance the prophetic and wisdom literature. 


\section{CONCLUSION}

Violence as theological problem in the Old Testament is far from resolved. According to Vervenne ${ }^{78}$ it is a fact that biblical scholarship has given very little attention to the reality of violence as an anthropological and theological theme. The remark by Lohfink in 1983 still holds true: "Nirginds taucht die Gewalt als grundsätzliche und alles zusammenhängend durchdringende Frage auf"79. Schwager ${ }^{80}$ also comments: "Dennoch dürfte unbestreitbar sein, dass die Theorie Girards ein neues Licht auf das zentralste alttestamentliche Thema wirft und dass sie direkt dazu herausfordert, durch die Analyse sehr vieler Einzeltexte die Frage nach der menschlichen und göttlichen Gewalt noch näher zu verfolgen". It is clear from this brief survey that there is still much to do to resolve the theological problem of violence in the Old Testament.

\section{NOTES:}

1 R Schwager, Brauchen wir eienen Sündenbock? Gewalt und Erlosung in den biblischen Schriften, München 1978, 58,65,70.

2 N Lohfink, (Hrsg) Gewalt und Gewaltlosigkeit im Alten Testament. Freiburg 1983, 17. M Vervenne, "Smeed uw ploegscharen om tot zwaarden!" (Joël $4,10)$, Verkenningen rond geweld en orlog in het Oude Testament, in: $R$ Burggraeve \& J De Tavenier (ed), Strijden op de weg van Jahwe, God, Allah!? De 'heilige oorlog' in het Oude Testament, westers christendom en islam, Leuven 1989, 38-39. M Vervenne, "Satanic Verses"? Violence and war in the Bible, in: R Burggraeve \& $\mathrm{M}$ Vervenne (eds), Swords into Plowshares, Theological Reflections on Peace, Louvain 1991, 91.

3 For a more detailed and chronological review of N Lohfink, "Gewalt als Thema alttestamentlicher Forschung", in: Lohfink (Hrsg), op cit, 15-50. Cf also Vervenne, op cit, 1991 and S D Snyman, Geweld - 'n onopgeloste probleem vir die Ou Testament. NGTT 31/3 (1990), 319-324.

$4 \quad$ Scwager, op cit, 76.

5 Cf also the remark of Schwager, op cit, 58, that "Kein andere menschliche Tätigkeit oder Erfahrung wird so oft verwähnt, weder die Welt der Arbeit und Wirtschaft, noch die der Familie und Sexualität oder der Naturerfahrung und des Wissen. Für die biblischen Autoren scheint die eindrucksvollste und bedrängendste Erfahrung gewesen zu sein, dass Menschen einander bekriegen und töten".

6 N Lohfink, “The unmasking of violence in Israel", Theology Digest 27 (1979), 104. 
7 A Schenker, Wege gewaltfreier Konfliktlösung im Alten Testament. Bibel und Kirche 2/2 (1982), 44.

8 J Ebach, Das Erbe der Gewalt. Eine biblische Realität und ihre Wirkungsgeschichte, Gütersloh 1980, 14.

9 E Villar, Does the Bible portray a violent God? Theology Digest 30/3 (1982), 204. Cf also E Noort, Geveld in her Oude Testament, Delft 1985.

10 Lohfink, op cit, 1979, 104; N Lohfink, Unsere grossen Wörter, Das Alte Testament zu Themen dieser Jahre, Freiburg 1985, 215; Schwager, op cit, 58.

11 D G Firth, Responses to violence in lament Psalms of the Individual, PhDdissertation, University of Pretoria, Pretoria 1996. Cf also D G Firth, Responses to violence in some lament Psalms of the individual, Skrif en Kerk $17 / 2$ (1996), 317-328.

12 Vervenne, op cit, 1991, 69; H D Preuss, Alttestamentliche Aspekte zu Macht und Gewalt, in: $\mathrm{H}$ Greifenstein (Hrsg), Macht und Gerialt, Leirlinien lutherischer Theologie zur politischen Ethik heute, Hamburg 1978. 114-134.

13 Ebach, op cir, 12-13.

14 Vervenne, op cit. 1989, 43-44.

15 W Brueggemann, Revelation and Violence: A Study in Contextualization. Wisconsin $1986,7$.

16 N Lohfink \& R Pesch, Weltgestaltung und Gewaltlosigkeit. Etische Aspekte des Alten und Neuen Testaments in ihrer Einheit und ihrem Gegensatz, Düsseldorf $1978,13$.

17 Schenker, op cit, 44.

18 Vervenne, op cit. 1991, 89-92.

19 Cf for instance the little attention paid to the voice of the Old Testament on the issue of violence in: J Ellul, Violence - Reflections from a Christian Perspective, New York 1979 and also P H Ballard, A Christian Perspective on Violence, London 1980. Cf also B J van der Walt (ed), Reflections on Power and Violence - Christian Perpectives, Potchefstroom 1990.

20 N Lohfink, "Der gewalttätige Gott des Alten Testaments und die Suche nach einer gewaltfreien Gesellschaft", Jahrbuch für Biblische Theologie 2 (1987), 108.

21 H Greifenstein (Hrsg), Macht und Gewalt - Leitlinien lutherischer Theologie zur politischen Ethik heute, Hamburg 1978. 
22 Cf Preuss, op cit, 1978, 130 writes: "Er kommt und schreitet einher in seiner grossen Kraft, wobei Menschen zertritt und dadurch sein Gewand mit Blut befleckt... Sein Geschichtsmächtigkeit schliesst Macht und Gewalt ein, nicht aber aus".

23 Schwager, op cit, 65.

24 Schwager, op cit, 1978, 66-72.

25 On the subject of the wrath of God of $\mathrm{H} \mathrm{G}$ L Peels, De Wraak van God. De Betekenis van de wortel NQM en de functie van de NQM-teksten in het kader van de Ouddrestamentische Godsopenbaring, Proefschrift ter verkrijging van de graad van Doctor in de Godgeleerdheid, Theologische Universiteit te Appeldoorn 1992.

26 Ebach, op cit, $18 \mathrm{ff}$.

27 Ebach, op cit, 34.

28 Lohfink \& Pesch. op cit, 1978. Lohfink, op cit, 1979, 103-106. Lohfink, Das Alte Testament: Aufdeckung und Krise der Gewalt, Bibel und Kirche 2/2 (1982), 38-44. Lohfink (Hrsg), op cit, 1983. Lohfink, op cit, 1985. Lohfink, op cit, 1987, 106-136.

29 Lohfink, op cit, 1985, 51; Lohfink, op cit, 1987, 108.

30 Lohfink, op cit. 1987, 116-118, 129.

31 Lohfink, op cit, 1978, 51; Lohfink, op cit, 1982, 40.

32 Vervenne, op cit, 1989, 57; Vervenne, op cit, 1991, 109.

33 Vervenne, op cit, 1989, 57; Vervenne, op cit, 1991, 110.

34 Many and extensive studies have been done on this subject, cf P C Craigie, The Problem of war in the Old Testament, Grand Rapids 1978. H Frederikson, Jahwe als Krieger, Lund 1945. G H Jones, "Holy War" or "Jahwe War"? VT 25 (1975), 642-658. S M Kang, Divine war in the Old Testament and in the Ancient Near East, (BZAW 177), Berlin 1989. M C Lind, Yahweh is a warrior. The theology of warfare in Ancient Israel, Scottdale PA 1980. F Stolz, Jahwe und Israels Kriege. Kriegstheorien und Kriegserfahrungen im Glauben des Alten Israels, (ATANT 60) Zurich 1972. G von Rad, Der heilige Krieg im alten Israel, (ATANT 20) Zurich 1951. [ET G von Rad, Holy War in Ancient Israel, Eerdmans 1991l. M Weippert. "Heiliger Krieg" in Israel und Assyrien. Kritische Anmerkungen zu Gerhard von Rads Konzept des "Heiligen Krieges im alten Israel", ZAW 84 (1972), 460-492. Cf also the bibliographies in Lohfink, op cit, 1983, 236ff and Vervenne, op cit, 1991, 117ff. 
36 Ebach, op cit, 22; Villar, op cit, 204.

37 Ebach, op cit, 24-26.

38 Ebach, op cit, 27.

39 Vervenne, op cit. 1991, 107.

40 Schwager, op cit, 1978.

41 Lohfink, op cit, 1982, 39, writes: "Ich selbst bin durch einen Dogmatiker, Raymund Schwager, auf diesen auch bei mir wirksam Verdrängungsmechanismus aufmerksam gemacht worden, als er sein Buch Brauchen wir eienen Sündenbock? Gewalt und Erlösung in den biblischen Schriften' vorbereitete und mich für das alttestamentliche Kapitel um Rat anging. Er machte mich auf die Schlüsselposition von Rene Girard aufmerksam..." Cf also Lohfink, op cit. 1978, 48.

42 Vervenne, op cit, 1989, 97

43 R Girard, La Violence et la sacre, Paris 1972.

44 R Girard, Violence and the Sacred. Baltimore 1977. The English translation is used in this article. Of course the theory of Girard will be highlighted only in so far as it pertains to its relevance for the debate on violence in the Old Testament. Cf also J G Williams, The Bible, Violence, and the Sacred. Liberation from the myth of sanctioned violence, San Francisco 1991, for an overview of Girard's theory as well as J G Williams, The Innocent Victim: Rene Girard on Violence, Sacrifice, and the Sacred, Religious Studies Review 14 (1988), 320-326.

45 Girard, op cit, 1977, 14-19.

46 Girard, op cit, 1977, 81.

47 Girard, op cit, 1977, 85-86.

48 Girard. op cit. 1977, 96-108; Lohfink, op cit, 1978. 45-47; Lohfink, op cit, 1979, 103; Lohfink. op cit, 1983, 45-46; Lohfink, op cit, 1987, 114; Schwager, op cit. 1978, 29-36.

49 G Pattison, Violence, Kingship and Cultus, Expository Times 102/5 (1991), 136.

$50 \quad$ Girard, op cit, 1977, 145. 
51 Girard, op cit. 1977, 145-148; Lohfink, op cit, 1978, 47; Schwager, op cit, 1978, 20-29.

52 Lohfink, op cit, 1983, 50; Lohfink, op cit, 1978, 45-48.

53 R North, Violence and the Bible, The Catholic Biblical Quarterly 47 (1985), 127.

$54 \quad$ P Ciholas, Monotheism and Violence, Theology Digest 32/1, (1985), 15-18.

55 Pattison, op cit, 135-139; O Dangl, Gewalt und Gewaltlosigkeit im Alten Testament, Unterrichtserfahrungen mit dem Thema, Bibel und Kirche 45/2 (1990), 100-106.

$56 \quad$ Vervenne, op cit, 1989, 56; Vervenne, op cit, 1991, 108

57 North, op cit. 1985, 21-27.

58 R Rüterswörden, Das Ende der Gewalt? Zu Rene Girards Buch, JBTh 2 (1987), 247-256.

$59 \quad$ Preuss, op cit, 124, 129.

60 Ebach, op cit, $34 \mathrm{ff}$

61 Ebach, op cit, 54-56.

62 Scwager, op cit, 119.

63 Schwager, op cit, 125.

64 Schwager, op cit, 129.

65 Schwager, op cit, 134.

66 Schwager, op cit, 141.

67 Lohfink, op cit, 1978, 49; Lohfink, op cit, 1987, 125, 127.

68 Lohfink, op cit, 1987, 119.

69 Lohfink, op cit, 1978, 58; Lohfink, op cit, 1979, 106; Lohfink, op cit, 1982 , 42-43.

70 Lohfink, op cit, 1978, 59; Lohfink, op cit, 1982, 43.

71 Lohfink, op cit, 1978, 59-60; Lohfink, op cit, 1979, 106; Lohfink, op cit, 1982, 43; Lohfink, op cit, 1987, 128. 
72 Villar, op cit, 205.

73 Vervenne, op cit. 1989, 59; Vervenne, op cit, 1991, 112.

74 A Schenker, Versöhnung und Sühne. Wege gewaltfreier Konfliktlösung im Alten Testament mit einem Ausblick auf das Neue Testament, Freiburg 1981.

75 Schenker, op cit, 1982, 44-50.

76 Schenker, op cit. 1981, 36-38.

77 Cf the contributions made by E Haag, Die Botschaft vom Gottesknecht - Ein Weg zur Überwindung der Gewalt, in: Lohfink, op cit, 1983, 159-213 and L Ruppert, Klagelieder in Israel und Babylonien - verschiedene Deutungen der Gewalt, in: Lohfink, op cit, 1983, 111-158.

78 Vervenne, op cit, 1991, 90.

79 Lohfink, op cit, 1983, 25

80 Schwager, op cit. 80-81. 